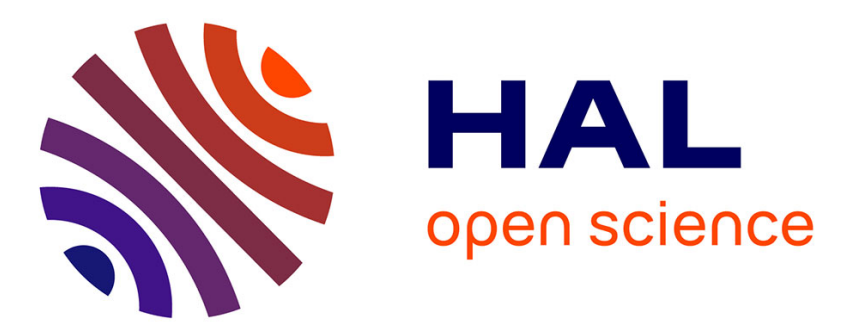

\title{
Some illustrations of large tectonically driven climate changes in Earth history
}

G. Ramstein, Y. Godderis, Y. Donnadieu, Pierre Sepulchre, F. Fluteau, Z. Zhang, R. Zhang, B. Su, D. Jiang, M. Schuster, et al.

\section{To cite this version:}

G. Ramstein, Y. Godderis, Y. Donnadieu, Pierre Sepulchre, F. Fluteau, et al.. Some illustrations of large tectonically driven climate changes in Earth history. Tectonics, 2019, 38 (12), pp.4454-4464. 10.1029/2019TC005569 . hal-02376697

\section{HAL Id: hal-02376697 https://hal.science/hal-02376697}

Submitted on 1 Apr 2021

HAL is a multi-disciplinary open access archive for the deposit and dissemination of scientific research documents, whether they are published or not. The documents may come from teaching and research institutions in France or abroad, or from public or private research centers.
L'archive ouverte pluridisciplinaire HAL, est destinée au dépôt et à la diffusion de documents scientifiques de niveau recherche, publiés ou non, émanant des établissements d'enseignement et de recherche français ou étrangers, des laboratoires publics ou privés. 


\section{Tectonics}

\section{RESEARCH ARTICLE \\ 10.1029/2019TC005569}

\section{Special Section:}

Fifty years of Plate Tectonics: then, now and beyond

Key Points:

- Relationships between paleogeographic configurations, climate, hydrological cycle and erosionto assess atmospheric $\mathrm{CO}_{2}$ changes

- Evaluations of climatic impact of uplifts (Tibetan Plateau and African rift) and epicontinental shrinkage (Paratethys) on Cenozoic climates

- Impacts on Tibetan Plateau uplift on Pacific and Atlantic meridional ocean circulationthrough Cenozoic

Correspondence to:

G. Ramstein,

gillesamstein@lsce.ipsl.fr

Citation:

Ramstein, G., Godderis, Y., Donnadieu, Y., Sepulchre, P., Fluteau, F., Zhang, Z., et al (2019). Some illustrations of large tectonically driven climate changes in Earth history. Tectonics, 38, 4454-4464. https://doi.org/10.1029/2019TC005569

Received 12 MAR 2019 Accepted 19 NOV 2019 Accepted article online 21 NOV 2019 Published online 25 DEC 2019

\section{Some Illustrations of Large Tectonically Driven Climate Changes in Earth History}

\author{
G. Ramstein ${ }^{1}$, Y. Godderis ${ }^{2}$, Y. Donnadieu ${ }^{3}$, P. Sepulchre ${ }^{1}$, F. Fluteau ${ }^{4}$, Z. Zhang ${ }^{5,6,7}$, R. Zhang ${ }^{6}$, \\ B. Su ${ }^{6}$, D. Jiang ${ }^{6,8,9}$, M. Schuster ${ }^{10}$, and J. Besse ${ }^{4}$ \\ ${ }^{1}$ Laboratoire des Sciences du Climat et de l'Environnement, LSCE/IPSL, CEA-CNRS-UVSQ, Université Paris-Saclay, Gif- \\ sur-Yvette, France, ${ }^{2}$ Géosciences Environnement Toulouse, CNRS-Université de Toulouse III, Toulouse, France, \\ ${ }^{3}$ CEREGE, Aix Marseille Univ, CNRS, IRD, INRA, Coll France, Aix-en-Provence, France, ${ }^{4}$ Institut de Physique du Globe \\ de Paris, Paris, France, ${ }^{5}$ Department of Atmospheric Science, School of Environmental Studies, China University of \\ Geosciences, Wuhan, China, ${ }^{6}$ Institute of Atmospheric Physics, Chinese Academy of Sciences, Beijing, China, ${ }^{7}$ NORCE \\ Research Climate, NORCE Norwegian Research Centre AS and Bjerknes Centre for Climate Research, Bergen, Norway, \\ ${ }^{8}$ University of Chinese Academy of Sciences, Beijing, China, ${ }^{9} \mathrm{CAS}$ Center for Excellence in Tibetan Plateau Earth \\ Sciences, Beijing, China, ${ }^{10}$ Institut de Physique du Globe de Strasbourg, UMR 7516, Université de Strasbourg, CNRS, \\ Strasbourg, France
}

\begin{abstract}
A century ago, the pioneering book published in 1924 Die Klimate der geologischen Vorzeit explained by plate motion the evolution of vegetation revealed in sedimentary records. Nevertheless, they did not invoke climate changes. In the second part of the 20th century, the intricate relationship between tectonics, long-term carbon cycle, and climate was depicted by Walker (1981). Since these major steps, climate modeling of the Earth system kept on improving and including more and more components and processes to enable the investigation of deep time periods using general circulation model that can account for atmosphere and ocean dynamics. Here we illustrate long but drastic climate changes clearly related with tectonics, through three different examples: (1) the crucial role of paleogeography (continental distribution) to explain the drawdown of atmospheric carbon dioxide and the huge glaciation associated that occurred during the Neoproterozoic period; (2) the shrinkage of large epicontinental Paratethys that covered a large part of Eastern Europe and Western Asia and its impact on both monsoonal systems (African and Asian) since $40 \mathrm{Ma}$; and (3) the large impact of mountain range uplifts since Eocene both in Asia (Tibetan Plateau and Himalaya) and in Africa (buildup of the rift), on atmosphere and ocean dynamics. These studies not only allow for testing the ability of Earth system models to capture long-term changes of Earth climate, but they also pinpoint the pivotal role tectonics played in shaping the long-term evolution of atmospheric $\mathrm{CO}_{2}$ and monsoon patterns.
\end{abstract}

Plain Language Summary For the celebration of the 50th anniversary of the publication of the pioneering papers that established the basis of plate tectonic, this paper was solicited to illustrate the close relation between tectonics and climate. Amongst the large spectrum of interactions that depict how tectonics modified the climate at geological time steps, we choose to illustrate two major issues: (1) How the "tryptic" climate/long-term carbon cycle/tectonics explains the extraordinary glacial episode (717-635 Ma) occurring during Neoproterozoic era? (2) How major tectonic events (i.e., the slow shrinkage of a huge epicontinental sea and the uplift of large mountains ranges in Asia and Africa) drastically changed the climate and shaped the pattern of present-day monsoons systems. This paper is the result of long-standing collaboration with many researchers from different countries.

\section{A Brief Introduction on Climate and Tectonic Interactions}

Preceding the 1968 revolution on the understanding of tectonics, many steps have been achieved at the beginning of the 20th century concerning the relationship of climate and plate motion. Pioneering work was provided as soon as 1924 by W. Köppen and A. Wegener in their famous book entitled Die Klimate der geologischen Vorzeit (Köppen \& Wegener, 1924, 2015). They pointed out the first pieces of a large puzzle that will be developed during the second part of the 20th century. In fact, in this paper, they clearly showed, in a 2-D world, the impact of plate motion on climate and continental biosphere. 


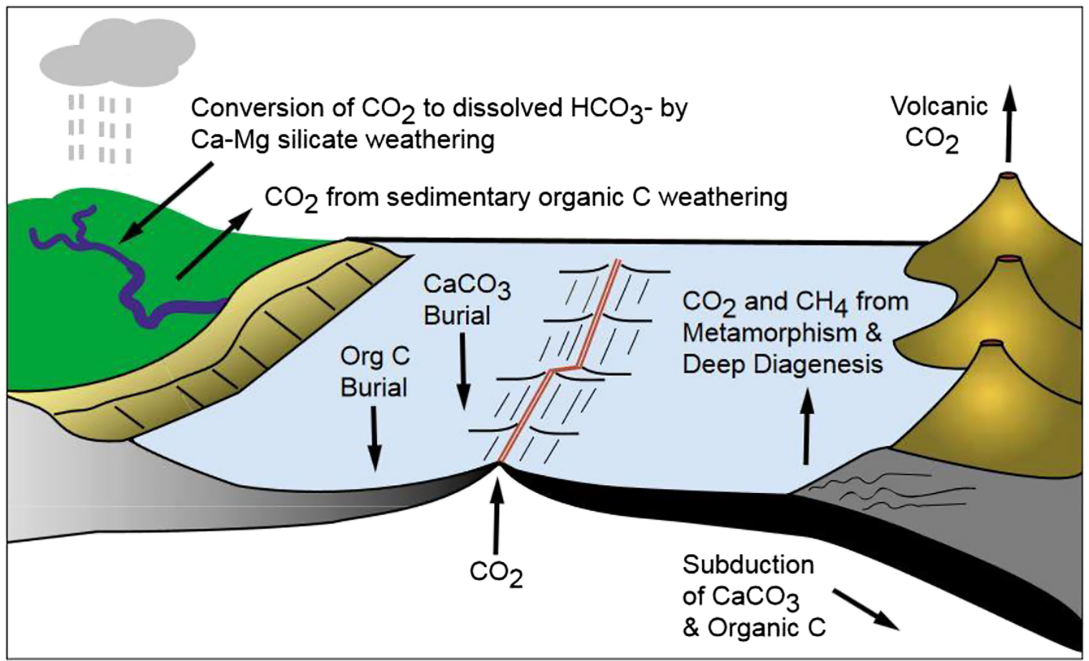

Figure 1. An idealized and simplified representation of the surficial aspects of the long-term carbon cycle. Note the exchange of carbon between rocks, on the one hand, and the oceans and atmosphere, on the other; this is the distinguishing characteristic of the long-term cycle (Berner, 1999).

The third dimension (vertical), which corresponds to mountain range uplift and decay, was not really accounted for. But the important step forward was the understanding of the fact that at a timescale of millions of years, plate motion plays a major role in climate evolution.

W. Köppen and A. Wegener were also aware of shorter timescale climate evolution due to orbital forcing. Indeed, they met and corresponded with Milutin Milanković as early as in 1920, as reported by Nikola Pantić in his biographical Sketch of Milanković (Milanković, 1998). Therefore, it can be considered that the concepts of climate changes in terms of driving forcing factors were mostly known at the beginning of the 20th century. Long-term latitudinal motion of continental masses and associated bathymetric changes on one hand and orbital forcing due to slow astronomical forcing both forcing are indeed superimposed but imprint the climate system at different timescales. The regular tempo of tectonics is related to tens of millions of years, whereas the oscillations of orbital forcings range from ten to hundreds of thousands of years.

Similar to the important progress that finally led to the understanding of major causes of plate motion and tectonics, many advances in the understanding of climate and tectonic relationships occurred during the second part of the 20th century. We can briefly summarize these advances by the following steps:

RG2006 FEULNER: THE FAINT YOUNG SUN PROBLEM

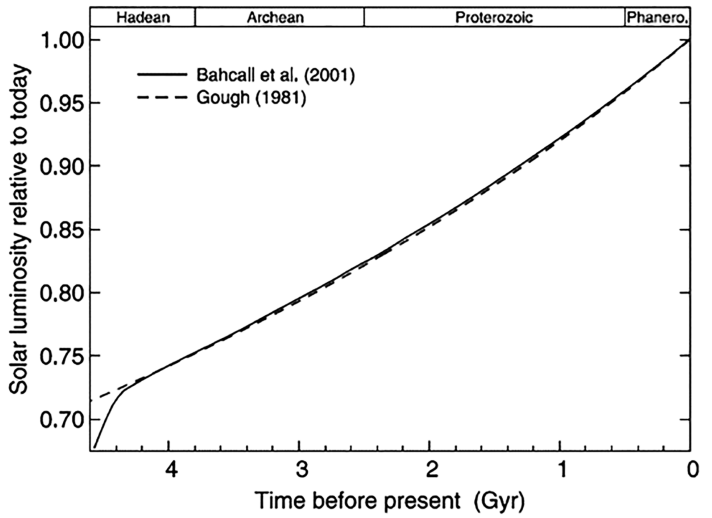

Figure 2. Evolution of solar luminosity over the four geological eons for the standard solar model described in Bahcall et al. (2001; solid line) and according to the approximation formula (Gough, 1981; dashed line; Feulner, 2012).
- The tectonics, climate, and carbon cycle tryptic

Walker et al. (1981) played a major role to reveal an indirect feedback that regulates temperatures through carbon and hydrological cycles (Figure 1). Superimposed to the direct climate effect of latitudinal shift of continental masses, the $\mathrm{CO}_{2}$ variations associated to tectonics were shown to deeply impact climate evolution (Berner, 2004) and its regulation (Walker et al., 1981). The concept of thermal regulation first described by James G. C. Walker may be summarized as follows: When most of continental shifted towards polar or subpolar latitude, the climate over them drastically cooled and also became drier. Indeed, the largest desert today is Antarctica and not Sahara. This huge decrease in precipitation inhibited silicate weathering, which is the dominant component of $\mathrm{pCO}_{2}$ sink at geological scale (Godderis et al., 2007). Therefore, if the source remains unchanged (volcano $\mathrm{pCO}_{2}$ emission), the $\mathrm{pCO}_{2}$ is stored in the atmosphere, and it is a greenhouse gas; it leads to temperature increase. This acts as a negative feedback, which counterbalances the paleogeographical impact. Reversely, when most of the continental masses are located between equatorial and tropical areas-where the Intertropical 

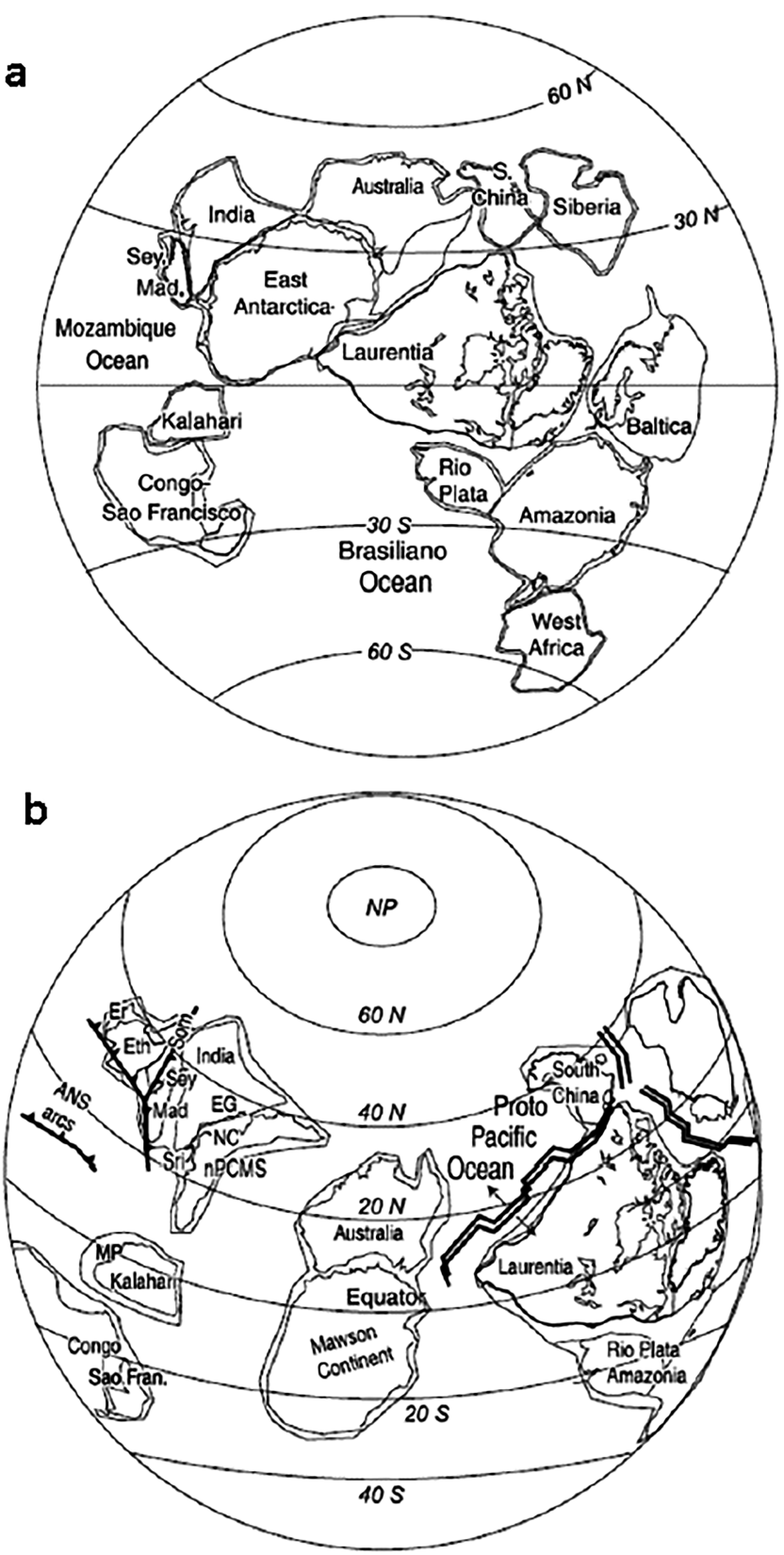

Figure 3. (a) The supercontinent Rodinia, about 800 million years ago and (b) the Rodinia dislocated about 750 million years ago. From paleoclimatology, Godderis chapter 5.
Convergence Zone plays a major role-precipitations are huge. Weathering is an important sink, and $\mathrm{CO}_{2}$ in the atmosphere therefore decreases. The direct effect of high temperatures due to the tropical location of continental masses is counterbalanced by the $\mathrm{CO}_{2}$ drawdown. These links between tectonics, carbon cycle, and climate evolution produce powerful negative feedbacks that regulate the Earth temperature at geological timescales.

The most striking illustration of the powerful feedback loop of the tectonics/carbon cycle/climate tryptic in terms of deregulation is certainly the Neoproterozoic snowball events occurring 717-635 Ma ago that we shall describe in section 2 .

As we discussed, tectonics has many consequences on climate evolution. On more recent periods, since Eocene, two major impacts occurred that will be depicted below. First, the large impact of the Paratethys shrinkage on monsoon systems in section 3 and major mountain ranges uplifts as indeed the Tibetan Plateau (TP) uplift and the African dome in section 4.

These examples illustrate how 3-D climate modeling advances, these last 20 years, have allowed to for investigating new frontiers.

Nevertheless, many questions are still open and will require further research such as the slow but irrepressible decrease of atmospheric $\mathrm{CO}_{2}$ concentration since Eocene. Last but not the least, the developments of Earth system model at the end of the 20th century mainly focused on climate variation made possible to simulate deep time climate, accounting for plate tectonics (bathymetry, continental distribution, mountain ranges, and atmospheric $\mathrm{CO}_{2}$ content). This new frontier has been deeply investigated during the last 30 years. The preliminary study only using atmosphere general circulation model was conducted by Ruddiman and Kutzbach (1989), followed by the simulations of Rind et al. (1997) which were the first performed with coupled atmosphere ocean general circulation model.

This paper will briefly illustrate how the tectonics/climate/carbon cycle can explain important transition on Earth climate from Precambrian to Quaternary.

\section{A Major Climate Deregulation During Neoproterozoic}

A major debate developed in the second part of the 20th century. After the evidences of ice cap in equatorial areas in the 60s by Harland, the snowball hypothesis has been disregarded for very simple radiative considerations. Indeed, if the Earth became a snowball, its albedo would increase from 0.3 to value higher than 0.6 . To escape such a frozen planet, using sun luminosity increase (7\% per billions of years, Figure 2) would take billions of years ... . Pioneering studies first conducted by Walker et al. (1981) and further developed by Kirschvink (1992) suggested, 30 years after Harland discovery, a much faster process to explain an escape. The factor allowing for a warming at times of millions of years instead of billions of years is volcanism. Indeed, on a completely frozen Earth, the $\mathrm{CO}_{2}$ emitted by volcanoes is stored in the atmosphere till its greenhouse impact produces a large deglaciation. At the end of last century, a scenario, mainly developed by Hoffman et al. (1998), allowed to solve many long-standing paradoxes concerning a hard snowball Neoproterozoic glaciation (i.e., completely glaciated Earth).

Recently, a new synthesis on snowball Earth episodes has been published by Hoffman et al. (2017), summarizing 20 years of research since his previous 1998 paper (Hoffman et al., 1998). This new study contains more than 500 references that shed light on major characteristics of the snowball Earth as, for instance, 


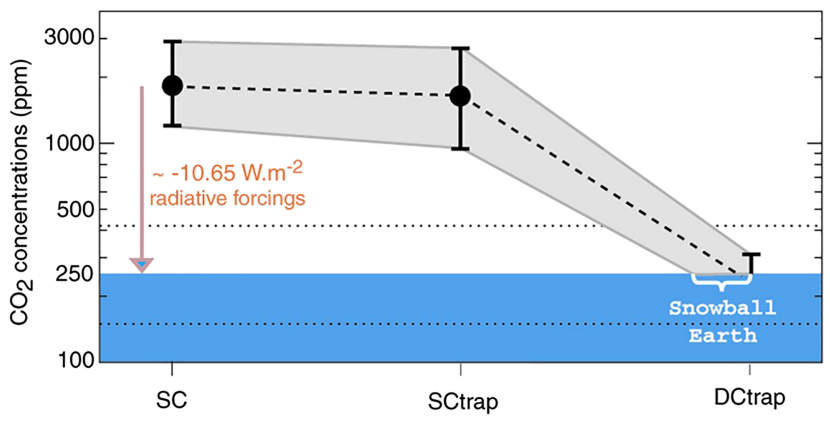

Figure 4. Atmospheric $\mathrm{CO}_{2}$ evolution during the time period preceding the Sturtian snowball event. Steady-state atmospheric $\mathrm{CO}_{2}$ level achieved by the GEOCLIM model for different configurations: The supercontinent configuration (SC) runs, for the SC runs with the inclusion of basaltic provinces (denoted SCtrap), and for the dispersed configuration (DC) runs also with basaltic provinces (denoted DCtrap; Donnadieu et al., 2004). chronology of glacial episodes (Macdonald et al., 2010), evolution of carbon dioxide in the atmosphere (Bao et al., 2008), and carbon cycle during a snowball Earth (Goddéris et al., 2003). Another intriguing question remains unsolved: Why although during most of the Proterozoic era, the Earth did not suffer major glaciation, did the cooling during the end of Proterozoic, so-called Cryogenian period, produce a drastic glaciation?

One of the driving factors that might have led to such an instability is tectonics. Indeed, the Wilson cycle corresponds to oscillations of around 500 Ma between a supercontinent and the spread of continental masses. A very peculiar breakup occurred for the Rodinia continent that formed $1.1 \mathrm{Ga}$ and began to break in small continental plates that remained in tropical area (Figure 3). This continental configuration for Rodinia corresponds to an optimal sink of atmospheric $\mathrm{CO}_{2}$ by silicate weathering (Figure 4; Godderis et al., 2007; Donnadieu et al., 2004; Hoffman et al., 2017).

Indeed, during Neoproterozoic, a very peculiar configuration of plate tectonics occurred. A supercontinent is located in the tropical band and spread into smaller plates that remained in the tropical band. This continental distribution provided ideal conditions to maximize silicate weathering, which is the major sink of atmospheric $\mathrm{CO}_{2}$ at geological timescales (Godderis et al., 2007). These conditions lead to a drastic $\mathrm{pCO}_{2}$ drawdown associated to a large cooling. Superimposed to this major effect, the large traps (Halverson et al., 2002), occurring during the break up of Rodinia created large basaltic provinces covering the granitic soil. Because basalt erodes much faster than
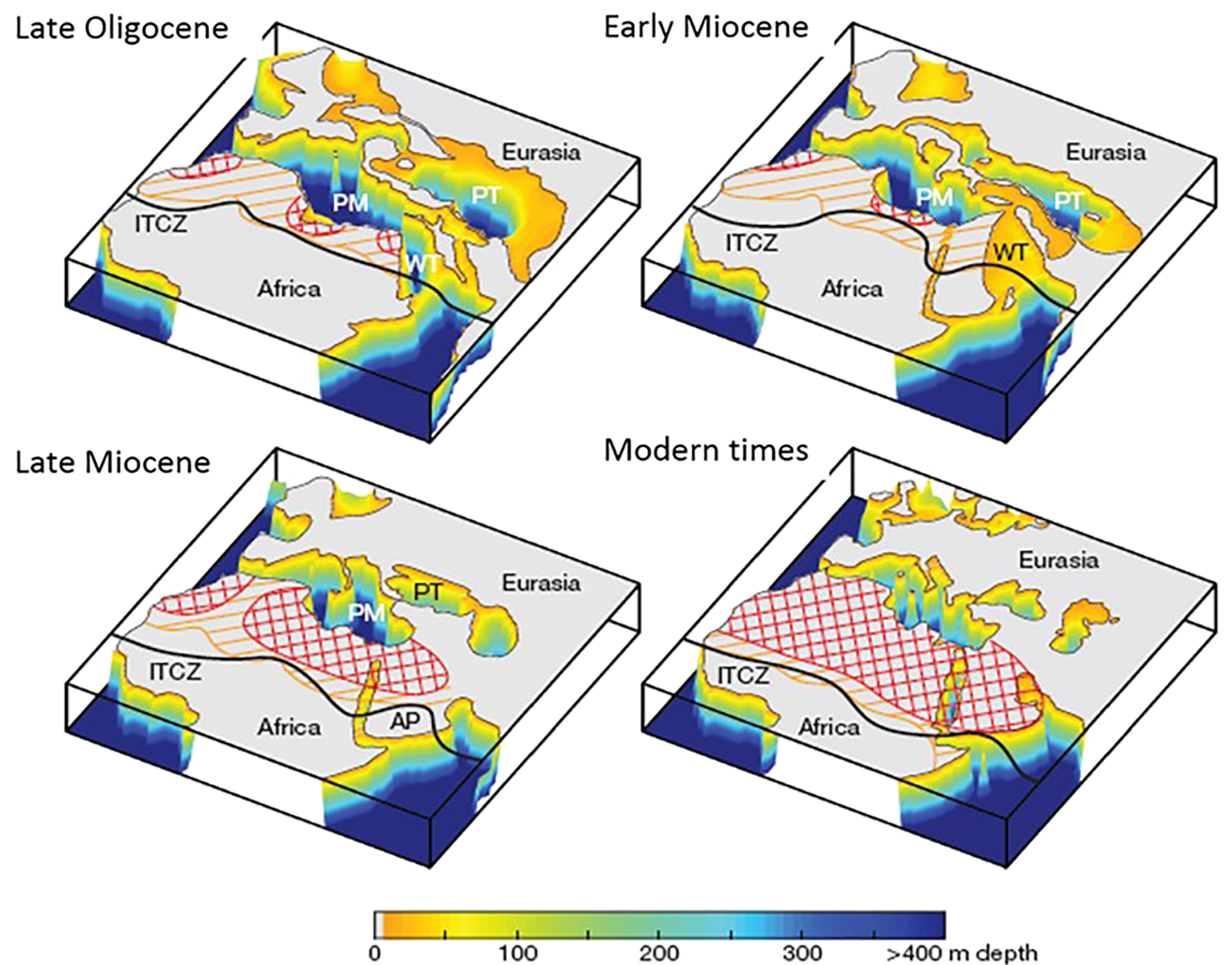

Figure 5. Tethys paleogeography and schematic north African palaeoclimate. Late Oligocene (a), Early Miocene (b), Late Miocene (c), and modern (d) time slices. The reconstructed Tethys bathymetry is based on the paleogeographical map created in Barrier and Vrielynck (2008) and Scotese (2001), showing the west Tethys Sea (WT), Paratethys Sea (PT), protoMediterranean Sea (PM), and Arabian peninsula (AP). Hatched areas show semiarid steppe climate (orange) and arid desert climate (red) from simulations, according to the Köppen climate classification. The black lines show the simulated climatological mean intertropical convergence zone (ITCZ) in summer (June to august), which is a measure of the intensity of the ASM (Zhang et al., 2014). 

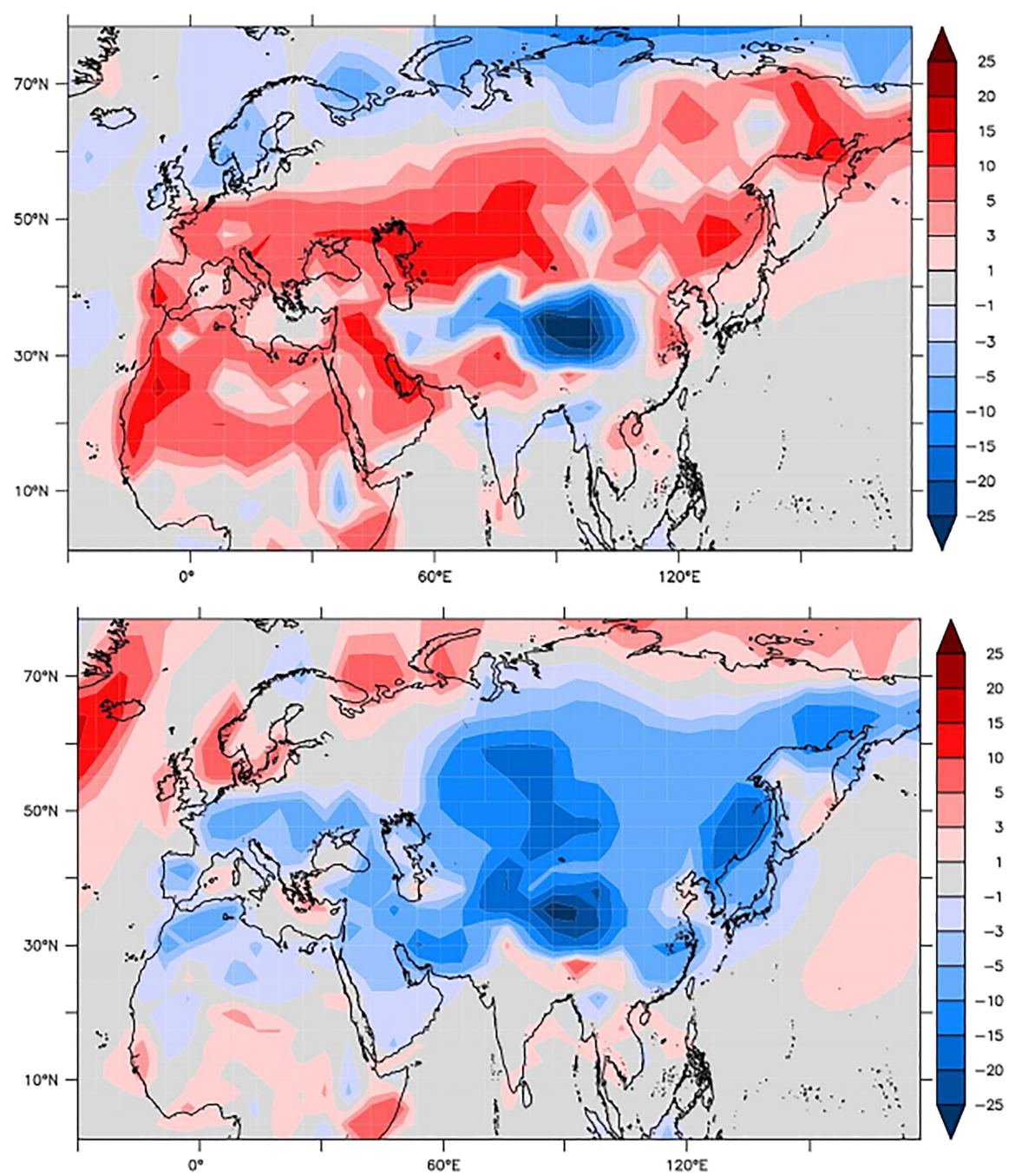

Figure 6. Anomaly in seasonal temperatures (JJA and DJF) between 30 ma and present day. Adapted from the Fluteau (1999) thesis.

granite this feature amplified the $\mathrm{CO}_{2}$ decrease and finally drove the climate towards the most important Earth glaciation (Figure 4).

\section{Consequences of Paratethys Shrinkage on Asian and African Monsoon Systems}

Modeling the transition from a more zonal climate to a monsoon-dominated climate from Miocene to Pliocene was investigated by pioneering works of Kutzbach et al. (1993), Vavrus and Kutzbach (2002) and Ruddiman (1997) that mostly focused on the causes of increased Asian monsoon. In these first studies, the authors mainly invoked the height of the TP as being able to produce a large increase of Asian monsoon in both intensity and area. More recent studies demonstrated that this first sensitivity using mainly atmospheric component was in fact very preliminary for many reasons. First, the spatial distribution of mountain ranges, after the India/Asia collision, is much more complex than the authors described (Boos \& Kuang, 2010; Zhang et al., 2017). Second, the estimates of paleoelevation using $\delta^{18} \mathrm{O}$ appeared to be too simple (Botsyun et al., 2016), and finally, the Asian monsoon evolution during Miocene was not well constrained. Nevertheless, these first simulations accounting for the uplift of the TP were useful to pinpoint the role of vertical tectonics. Another major tectonic event during the same time period is the shrinkage of Paratethys (see Figure 5; Dercourt et al., 1993). This huge epicontinental sea spreading over Eastern Europe and Western Asia at Eocene was drastically reduced till Tortonian (11-7 Ma). In the Late 

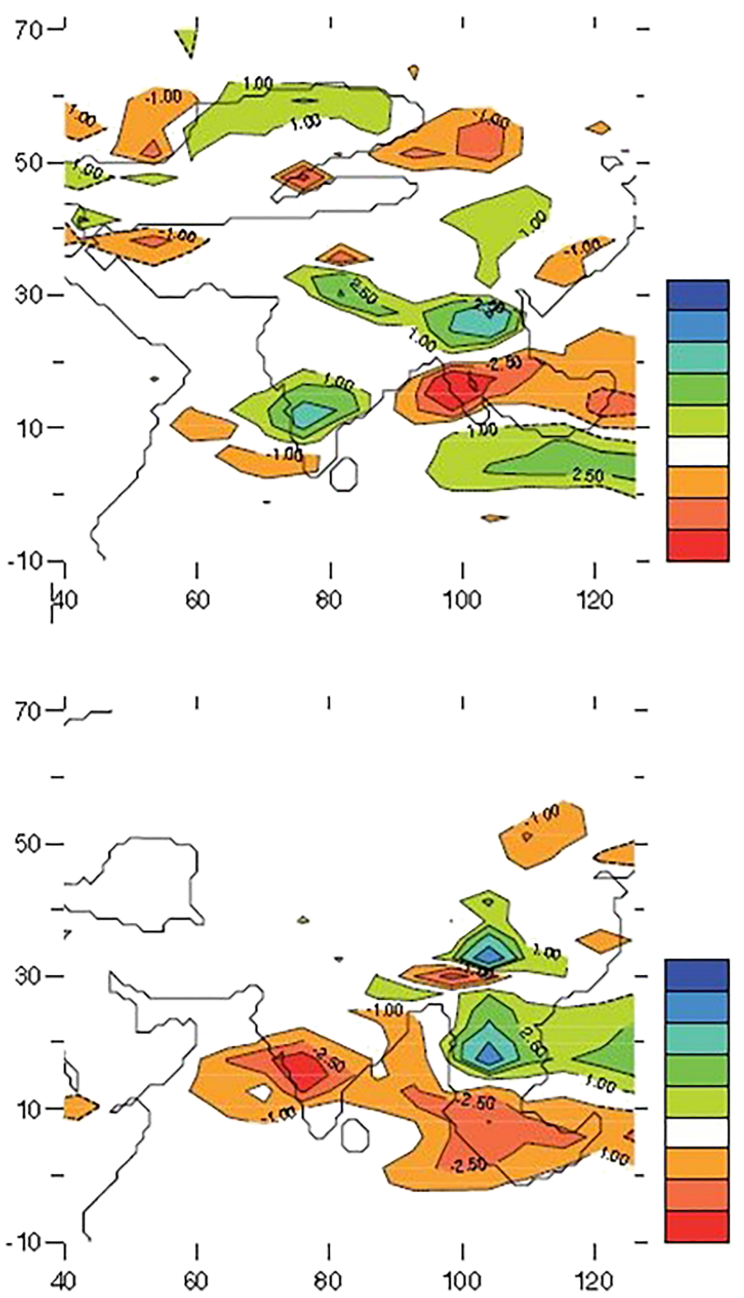

Figure 7. Summer (JJA) precipitations difference. Adapted from the Fluteau (1999) thesis.
Oligocene and Early Miocene, the Tethys was still large, with the West Tethys seaway connecting the proto-Mediterranean Sea to the Indian Ocean (Barrier \& Vrielynck, 2008; Rögl, 1999; Scotese, 2001). The AfroArabian and Eurasian plates collided during the Middle Miocene, closing the West Tethys seaway (Rögl, 1999). Finally, during the Tortonian stage (11-7 Ma) of the Late Miocene, the West Tethys was replaced by the Arabian Peninsula, and the Paratethys became much smaller (Figure 5; Barrier \& Vrielynck, 2008).

Caspian, Black, and Mediterranean seas are today relics of this huge water body. The first studies accounting for the Paratethys shrinkage (Fluteau et al., 1999; Ramstein et al., 1997; Zhang et al., 2007) demonstrated that it drastically enhances the seasonal cycle: much warmer temperatures in summer and cooler temperatures in winter leading to an increase of summer and winter monsoon (Figure 6).

Moreover, we quantify, through sensitivity simulations, the separated impact of the TP uplift and the Paratethys shrinkage (Figure 7). More recently, the impact of such a shrinkage over Africa has also been investigated using a more recent coupled ocean-atmosphere general circulation model (Zhang et al., 2014) showing the drastic impact of this shrinkage on hydrological cycle and especially on aridification of North Africa triggering the onset of the Sahara desert (Figure 8). This result is important because it occurs at the emergence of humankind corresponding to the discovery of Sahelanthropus tchadensis (Toumaï, Brunet et al., 2002).

\section{Asian and African Uplifts and Climate Changes}

\section{- Accounting for vertical motion}

William Ruddiman in his book Tectonic Uplift and Climate Change summarized the different impact of the onset, development, and decay of mountain ranges since Eocene. His studies were mostly focused on atmospheric changes and $\mathrm{pCO}_{2}$ variations linked with mountain range uplift. This is mostly illustrated by the TP and Himalaya uplift during Cenozoic period (France-Lanord \& Derry, 1997; Galy \& France-Lanord, 2001; Raymo \& Ruddiman, 1992).

The numerous studies devoted to the climate sensitivity and more especially the monsoon evolution associated with increase elevation of TP did not capture the whole impact of tectonics on climate. Indeed, as seen
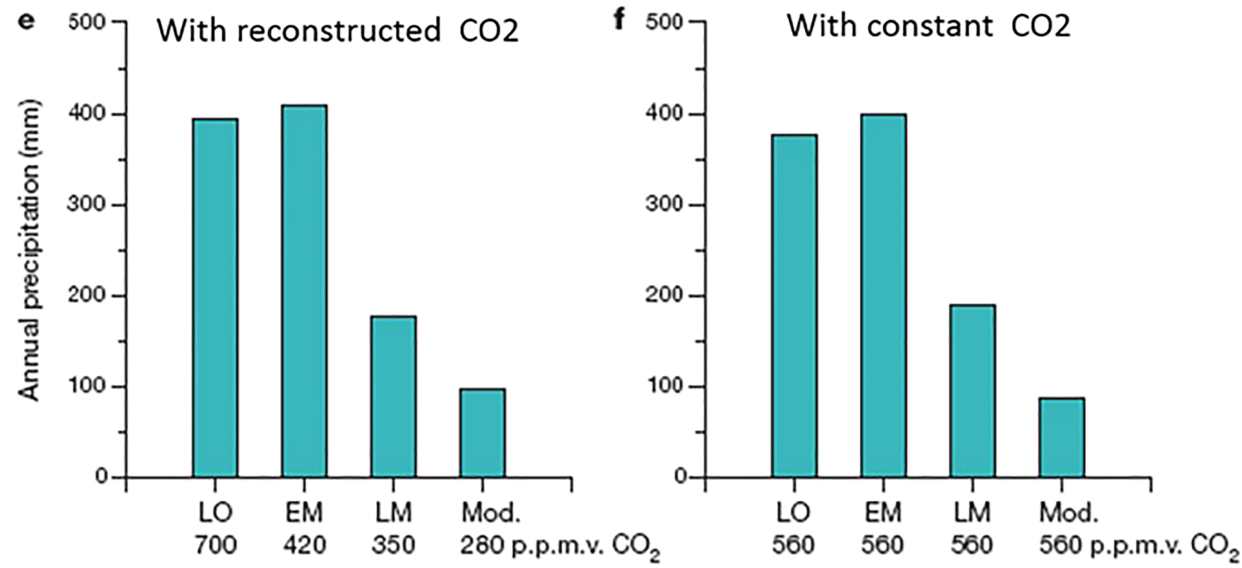

Figure 8. Annual precipitation ( $\mathrm{mm}$ ) averaged over North Africa in the late Oligocene (LO), Early Miocene (EM), Late Miocene (LM), and modern experiments (mod.) with the indicated atmospheric $\mathrm{CO}_{2}$ levels (Zhang et al., 2014). 

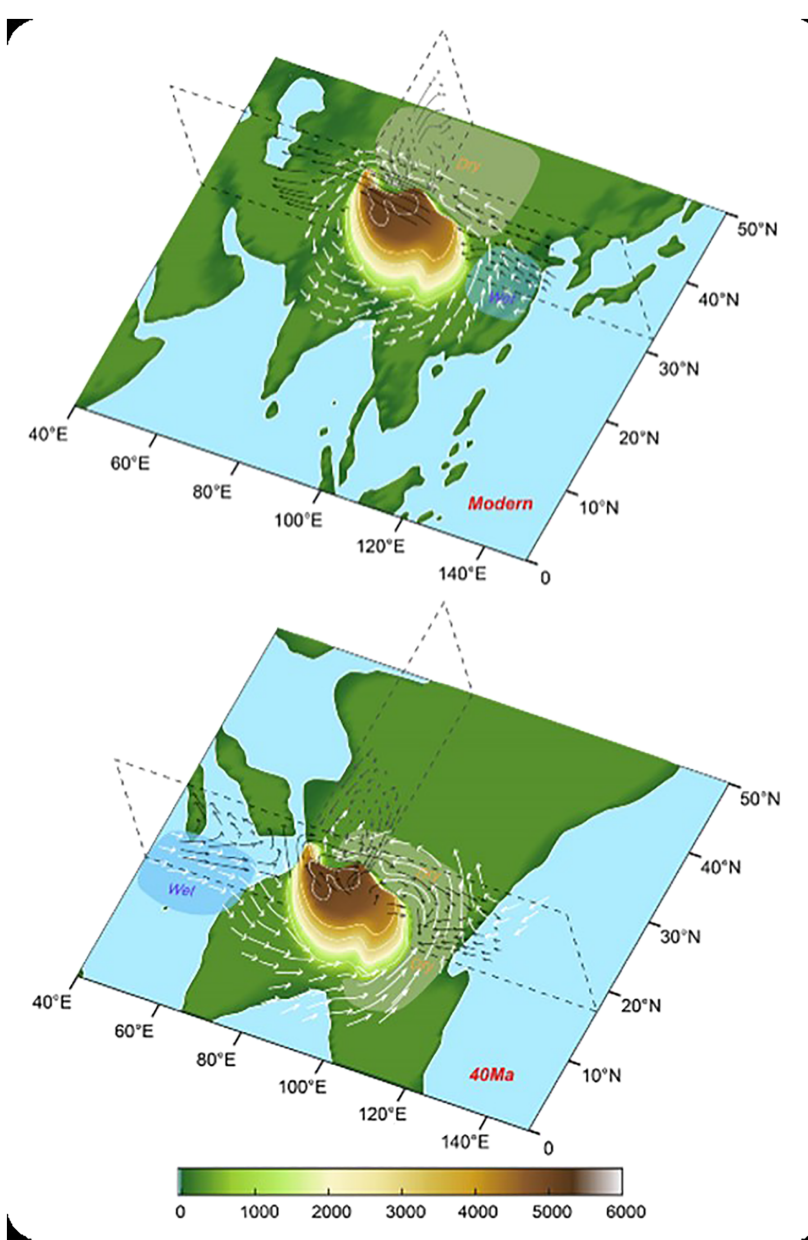

Figure 9. Cartoon illustrating the impact of the latitude of the HimalayaTibetan plateau (TP) on Asian climate. The rise of the Himalaya-TP in the subtropics intensifies aridity throughout inland Asia north of $\sim 40^{\circ} \mathrm{N}$ and enhances precipitation over East Asia. In contrast, the rise of the HimalayaTP in the tropics only slightly intensifies aridity in inland Asia north of $\sim 40^{\circ}$ $\mathrm{N}$ and slightly increases precipitation in East Asia. Areas with dark blue (light green) coloring indicate increased (decreased) precipitation. Arrows with white (black) coloring indicate the response of vertically integrated water vapor transport (vertical circulation) to the surface uplift of the Himalaya-TP (for interpretation of the references to color in this figure, the reader is referred to the web version of this article; Zhang et al., 2018). in the previous section, another proximal tectonic event occurred during the same period: the Paratethys shrinkage, but focusing only on Indian/Asian collision, many more aspects have to be accounted for. The history of the mountain ranges and the chronology is important to simulate the monsoon evolution and the aridification of inland China (Zhang et al., 2017) and also the latitudinal shift of the TP from the collision in the tropical location to the present location in subtropical latitude (Zhang et al., 2018). The collision indeed impacts not only the height of the TP, which has been demonstrated to be very difficult to constrain by $\delta^{18} \mathrm{O}$, but also latitudinally. From the Eocene collision to quaternary, the mountain shifted northward by more than 2,000 km (Zhang et al., 2018). The southern margin of a proto-Himalaya-TP, however, was located at least partially in the high tropics in the early Cenozoic (Lippert et al., 2014; Van der Voo et al., 1999; van Hinsbergen et al., 2011). In the early stages of the India-Asia collision, from $\sim 60$ to $\sim 40 \mathrm{Ma}$ (Najman et al., 2010), the southern margin of the proto-Himalaya-TP was located more than 1,000 $\mathrm{km}$ south of its present position, with the southernmost latitude of the orogenic system estimated to be at $\sim 16^{\circ} \mathrm{N}$ (Huang et al., 2015; Lippert et al., 2014).

Therefore, the interaction of atmospheric circulation with the TP is drastically different depending on whether this interaction took place in the tropics or subtropics (Figure 9). One of the most striking effects, accounting for this latitudinal shift, is the impact on hydrological cycles and Asian monsoon. Indeed, the latitudinal shift has to be associated to vertical motion of the mountain ranges; therefore, several reconstructions have to be tested to infer the spatial evolution of the hydrological cycle to point out the changes on monsoon evolution for different configurations.

Another important aspect that was not investigated by numerous studies that focused mostly on atmospheric changes induced by the TP uplift (Rind et al., 1997; Su et al., 2018; Vavrus \& Kutzbach, 2002) is the impact on ocean dynamics. More recent studies described with greater accuracy the consequences not only of TP but also of Himalayan ranges (Boos \& Kuang, 2010) and disentangled the elevation and albedo effects. To investigate the TP on ocean circulation requires long ocean-atmosphere general circulation model simulations (Su et al., 2018). Such simulations run with ocean-atmosphere general circulation model show a drastic change of the Northern Hemisphere Meridional Ocean Circulation. When the TP is removed, the Pacific Meridional Ocean Circulation is important and the Atlantic Meridional Ocean Circulation is low. Conversely for the present-day situation, with a large TP, the Atlantic Meridional Ocean Circulation is high and the Pacific Meridional Ocean Circulation is low (see Figure 10). These results pinpoint the large impact of this uplift on ocean dynamics.

Last but not least, the African dome shaped the climate in which took place human ancestors evolution. Similarly to other mountain ranges (Rind et al., 1997), the chronology of the African dome spanned over more than $30 \mathrm{Ma}$ (Partridge, 1997; Sepulchre et al., 2006) and is not well constrained. Modeling studies focused mainly on climate sensibility to the elevation of the dome using very simplified configurations (Figure 11). The climate simulations showed that the African dome uplift drastically impacts the East African climate. When the dome is low, large precipitation occur and maintain wet and warm conditions favorable to forests, while the present-day elevation leads to a large aridification that favors the herbaceous instead of arboreal vegetation cover (Figure 12).

These changes have imprinted the environmental conditions of the evolution of our ancestors at the PlioPleistocene boundary. 


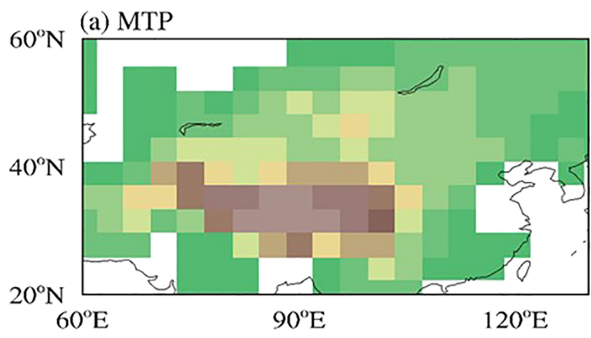

(c) SAT and temperature at $1000 \mathrm{~m}$
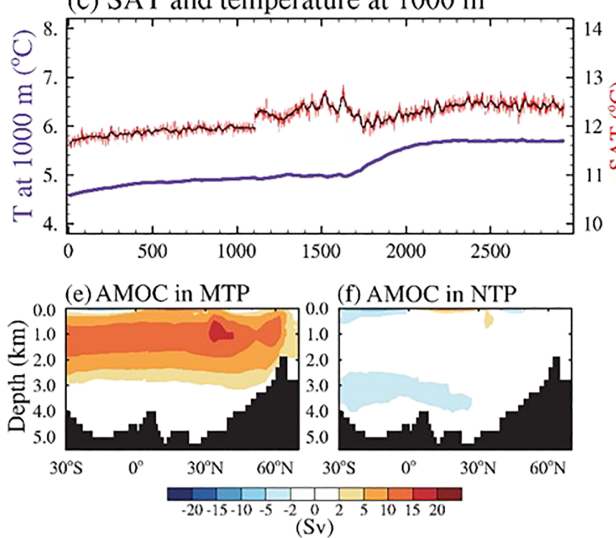

(b) NTP

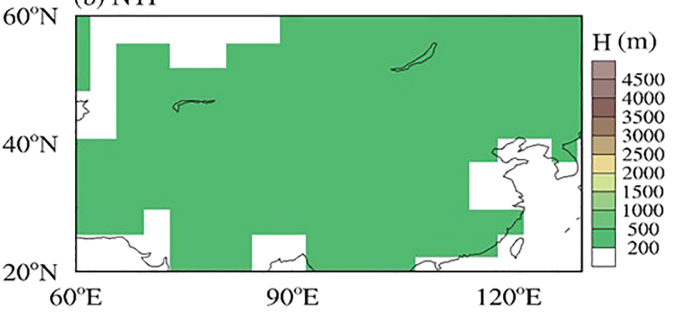

(d) PMOC and AMOC indices
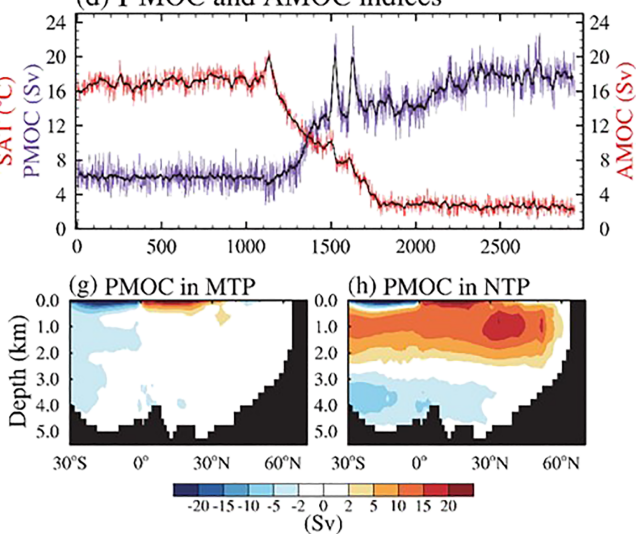

Figure 10. Two topographic height configurations used in experiments: (a) Modern Tibetan Plateau (MTP) and (b) No Tibetan Plateau (NTP, the elevation has been fixed to $200 \mathrm{~m}$ ). (c) Time series of global mean annual 2-m surface air temperature (SAT) and sea temperature at 1,000 m depth in MTP (1-1,100 years) and NTP (1,101-2,940 years) simulations; bold black lines show the 21-year running mean. (d) Same as (c) but for PMOC and AMOC indices. AMOC and $\mathrm{PMOC}$ indices are defined as the annual maximum of the meridional stream function value north of $28^{\circ} \mathrm{N}$ and below the depth of $500 \mathrm{~m}$ over the North Atlantic and Pacific, respectively. (e-h) Climatological annual mean Atlantic and IndianPacific meridional overturning stream function in (e, g) MTP and (f, h) NTP; positive (negative) shading represents clockwise (counterclockwise) circulations.

Another important feature also occurred during this period. Indeed, since $34 \mathrm{Ma}$, only the Southern Hemisphere hosted an ice sheet over Antarctica due to the long $\mathrm{pCO}_{2}$ decrease and the opening of the Drake seaway (Ladant et al., 2014; Livermore et al., 2005). It has been necessary to wait more than 30 million years to achieve very low $\mathrm{pCO}_{2}$ that enable an ice sheet to grow and maintain over Greenland (Tan et al., 2018). The evolution of our ancestors took place in the warmest part of a cold world with very low $\mathrm{pCO}_{2}$ content during Quaternary.

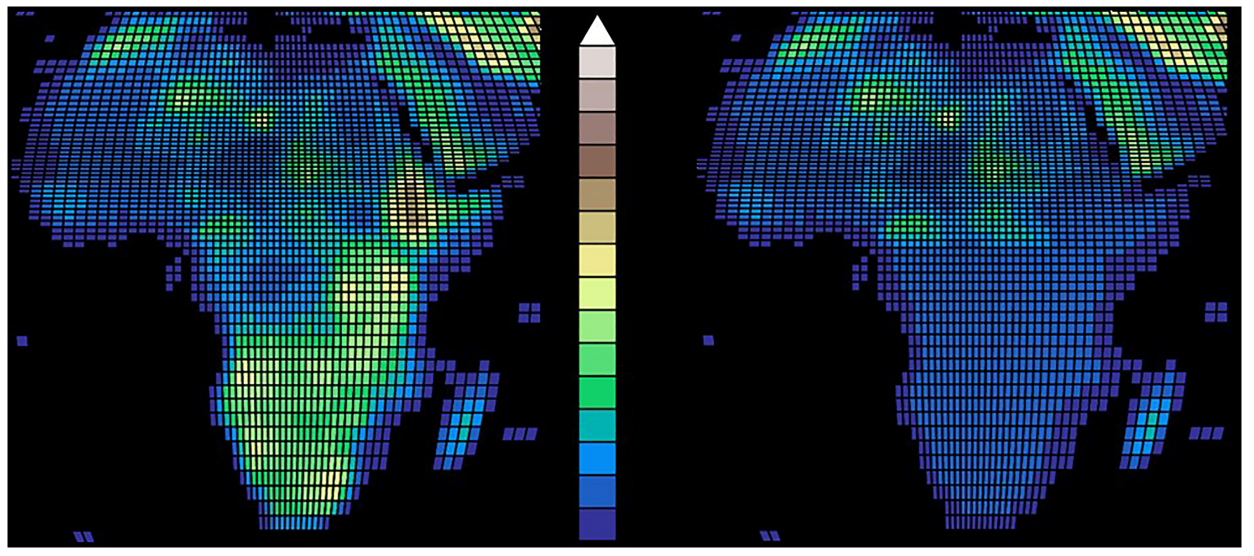

Figure 11. Experimental design of two LMDz4 simulations related to topographic history of Africa. Left, elevation interpolated at the LMDz model resolution for present-day conditions. Right, experiment NORIFT, where the elevation has been set to $200 \mathrm{~m}$ over eastern and southern African domes (modified from Sepulchre et al., 2006). 
A

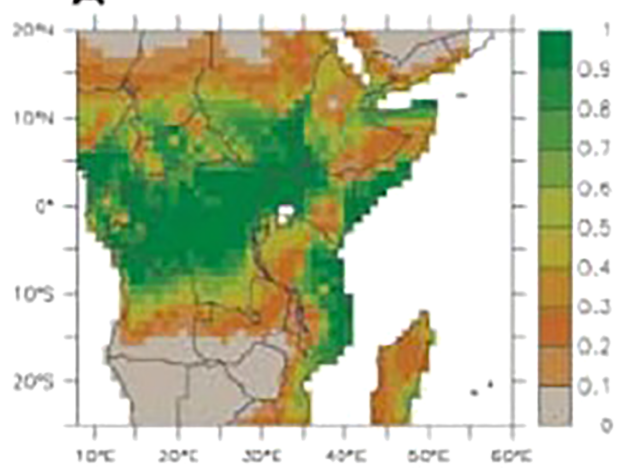

B

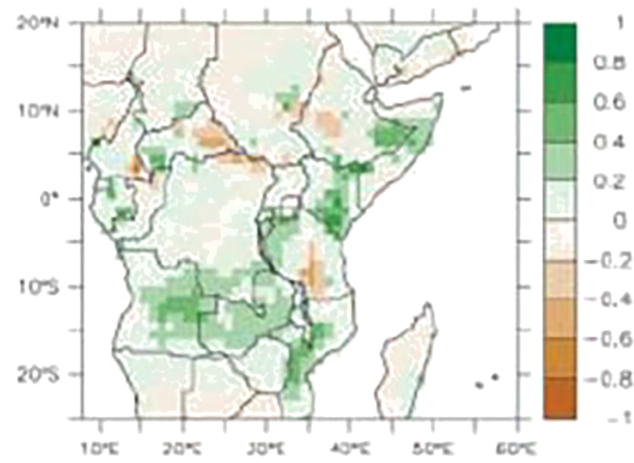

C

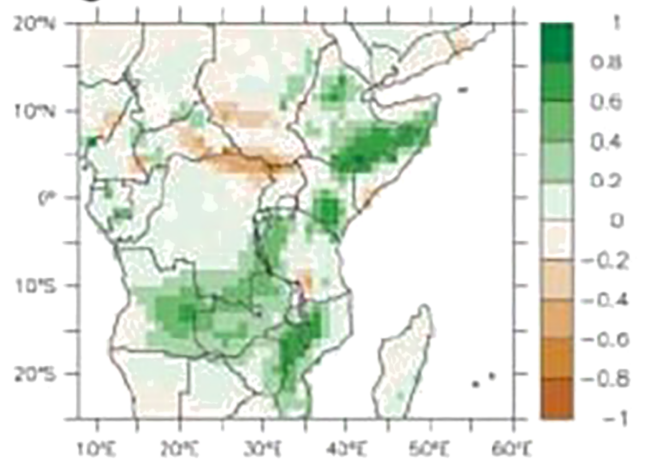

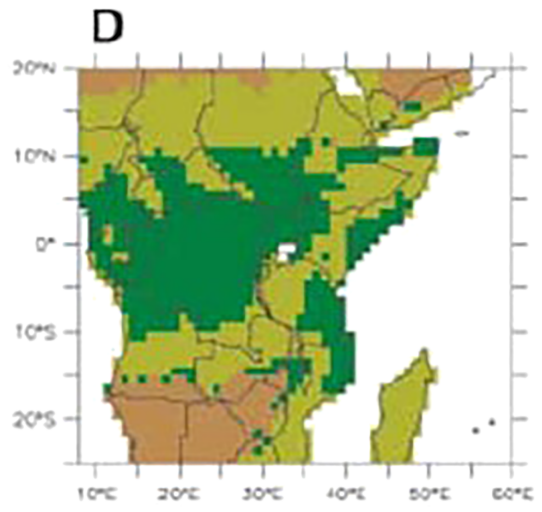

E

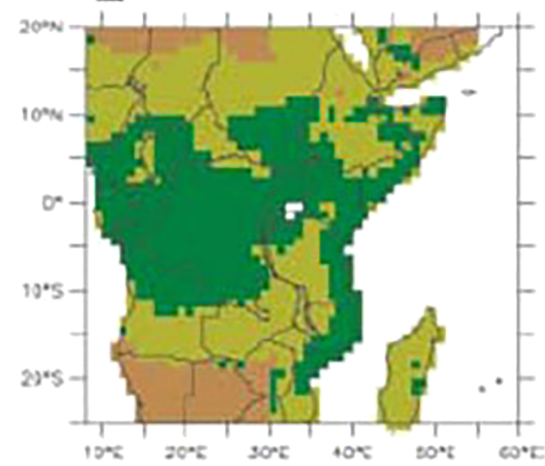

F

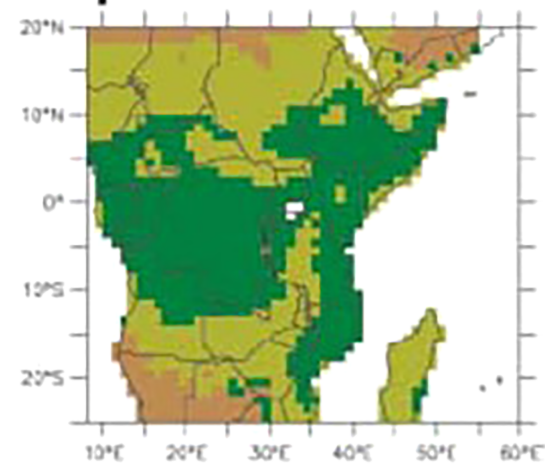

Arboreal $>$ Herbaceous

Arboreal $<$ Herbaceous

Total cover < $5 \%$

Figure 12. Simulated vegetation for the three experiments. (a) Summed vegetation fraction over every PFT (plant functional type) for the CTL run. Zero value indicates the absence of vegetation; 1 represents a grid point totally covered by PFTs. (b and c) anomalies of TRAPS and NODOME minus CTL, respectively. (d-f) Arborealdominant, herbaceousdominant, and desert-like fractions for CTL, TRAPS, and NODOME, respectively. We note the massive spreading of arboreal fraction at the expense of herbaceous fraction over eastern Africa (Sepulchre et al., 2006).

\section{Conclusions}

These different illustrations depict how tectonics drove climate change at geological timescale. This control was first investigated as a radiative change process associated with the impact of plate motion. We show, in the second step, that tectonics actually deeply imprint not only atmosphere but also ocean dynamics. More importantly, tectonics can explain, through its intricate relationships with carbon cycle and climate, the regulation of temperature and hydrology at the Earth surface. In such a short 
contribution, we chose a focus on the large climatic impact of major tectonic events, but there are many other possible illustrations. For instance, the bathymetry and shape of ocean basins is also shaped by tectonics. These changes may produce long-term climatic variations and also rapid reorganizations of ocean dynamics when seaways open or close (Cane \& Molnar, 2011; Hamon et al., 2013; Sepulchre et al., 2014; Tan et al., 2017; Zhang et al., 2011). Therefore, in future modeling studies, the very long history of our planet offers the opportunity to explore many exciting issues using a hierarchy of climate models. This will certainly shed light on tectonics, carbon cycle (biotic or abiotic), and climate interactions. Another reason why to investigate Cenozoic warm climates is the fact that the ongoing Anthropocene perturbation will lead to unprecedented $\mathrm{pCO}_{2}$ values during Quaternary, which is characterize by extremely low $\mathrm{pCO}_{2}$ values. These predicted $\mathrm{pCO}_{2}$ values for the end of 21 st century around $500 \mathrm{ppmv}$ correspond to warm climate of the Cenozoic; therefore, exploring the atmosphere/ocean/vegetation/cryosphere interactions in a high $\mathrm{pCO}_{2}$ world is an important climate issue.

\section{Acknowledgments}

We are very grateful to Sarah Amram (LSCE) for her help. These different studies were funded successively by the CNRS (France) multidisciplinary program ECLIPSE (paleoclimate and related fields, 2000-2007); the PHC AURORA project "Investigation of weaker and stronger obliquity responses during the Pliocene and the Pleistocene" (Norway-France) funded by foreign office minister (34056NG, 2015); the PHC CAI YUANPEI project "Impact of the Tibetan Plateau on climate for the last 40 million years" (China-France) funded by foreign office minister (36722PK_2016-2018), and the ANR ACCRO-EARTH project

(Accidents in Climate Carbon-cycle Regulation of the Earth) of the French National Research Agency (ANR-06BLAN-0347-CSD6). All the data used are available in the references cited herein.

\section{References}

Bao, H.-M., Lyons, J. R., \& Zhou, C. (2008). Triple oxygen isotope evidence for elevated $\mathrm{CO}_{2}$ levels after a Neoproterozoic glaciation. Nature, 453(7194), 504-506. https://doi.org/10.1038/nature06959

Barrier, E., \& Vrielynck, B. (2008). Palaeotectonic maps of the Middle East. Commission for the Geological Map of the World

Bahcall, J. N., Pinsonneault, M. H., \& Basu, S. (2001). Solar models: Current epoch and time dependences, neutrinos, and helioseismological properties, Astrophysical Journal, 555, 990-1012. https://doi.org/10.1086/321493

Berner, A. R. (1999). A new look at the long-term carbon cycle. GSA Today, 9(11)

Berner, A. R. (2004). The Phanerozoic Carbon Cycle $\mathrm{CO}_{2}$ and $\mathrm{O}_{2}$. New York: Oxford University Press.

Boos, W. R., \& Kuang, Z. (2010). Dominant control of the south Asian monsoon by orographic insulation versus plateau heating. Nature, 463(7278), 218-222. https://doi.org/10.1038/nature08707

Botsyun, S., Sepulchre, P., Risi, C., \& Donnadieu, Y. (2016). Impacts of Tibetan plateau uplift on atmospheric dynamics and associated precipitation $\delta^{18} \mathrm{O}$. Climate of the Past, 12(6), 1401-1420. www.clim-past.net/12/1401/2016/, https://doi.org/10.5194/cp-12$1401-2016$

Brunet, M., Guy, F., Pilbeam, D., Mackaye, H. T., Likius, A., Ahounta, D., et al. (2002). A new hominid from the Upper Miocene of Chad, Central Africa. Nature, 418(6894), 145-151. https://doi.org/10.1038/nature00879

Cane, M. C., \& Molnar, P. (2011). Closing of the Indonesian seaway as a precursor to east African aridification around 3-4 million years ago. Nature, 411(6834), 157-162. https://doi.org/10.1038/35075500

Dercourt, J., Ricou, L. E., \& Vrielynck, B. (1993). Atlas Tethys palaeoenvironmental maps Atlas and explanatory notes. In G. Villars (Ed.), Diffusion. Paris: CGMW. 307 p., 14 maps

Donnadieu, Y., Goddéris, Y., Ramstein, G., Nedelec, A., \& Meert, J. (2004). A ‘snowball Earth' climate triggered by continental break-up through changes in runoff. Nature, 428(6980), 303-306. https://doi.org/10.1038/nature02408

Feulner, G. (2012). The faint young sun problem. Reviews of Geophysics, 50, RG2006. https://doi.org/10.1029/2011RG000375

Fluteau, F. (1999). Impact de la tectonique des plaques sur le climat (thesis). University of Paris-Diderot.

Fluteau, F., Ramstein, G., \& Besse, J. (1999). Simulating the evolution of the Asian and African monsoons during the past 30 Myr using an atmospheric general circulation model. Journal of Geophysical Research, 104(D10), 11,995-12,018. https://doi.org/10.1029/ 1999JD900048

France-Lanord, C., \& Derry, L. A. (1997). Organic carbon burial forcing of the carbon cycle from Himalaya erosion. Nature, 390(6655), 65-67. https://doi.org/10.1038/36324

Galy, A., \& France-Lanord, C. (2001). Higher erosion rates in the Himalaya: Geochemical constraints on riverine fluxes. Geology, 29(1), 23-26. https://doi.org/10.1130/0091-7613(2001)029<0023:HERITH>2.0.CO;2

Godderis, Y., Donnadieu, Y., Dessert, C., Dupre, B., Fluteau, F., François, L. M., et al. (2007). Coupled modeling of global carbon cycle and climate in the Neoproterozoic: Links between Rodinia breakup and major glaciations. Comptes Rendus Geosciences, 339(3-4), 212-222. ISSN 1631-0713. https://doi.org/10.1016/j.crte.2005.12.002

Goddéris, Y., Donnadieu, Y., Nédélec, A., Dupré, B., Dessert, C., Grard, A., et al. (2003). The Sturtian 'snowball' glaciation: Fire and ice. Earth and Planetary Science Letters, 211(1-2), 1-12. https://doi.org/10.1016/S0012-821X(03)00197-3

Gough, D. O. (1981). Solar interior structure and luminosity variations. Solar Physics, 74(1), 21-34. https://doi.org/10.1007/BF00151270

Halverson, G. P., Hoffman, P. F., Schrag, D. P., \& Kaufman, A. J. (2002). A major perturbation of the carbon cycle before the Ghaub glaciation (Neoproterozoic) in Namibia: Prelude to snowball Earth? Geochemistry, Geophysics, Geosystems, 3(6), 1035. https://doi.org/ 10.1029/2001GC000244

Hamon, N., Sepulchre, P., Lefebvre, V., \& Ramstein, G. (2013). The role of eastern Tethys seaway closure in the Middle Miocene Climatic Transition (ca. 14 Ma). Clim. Pastoralism, 9(6), 2687-2702. https://doi.org/10.5194/cp-9-2687-2013

van Hinsbergen, D. J. J., Kapp, P., Dupont-Nivet, G., Lippert, P. C., DeCelles, P. G., \& Torsvik, T. H. (2011). Restoration of Cenozoic deformation in Asia and the size of greater India. Tectonics, 30, TC5003. https://doi.org/10.1029/2011TC002908

Hoffman, P. F., Abbot, D. S., Ashkenazy, Y., Benn, D. I., Brocks, J. J., Cohen, P. A., et al. (2017). Snowball Earth climate dynamics and Cryogenian geology-geobiology. Science Advances 08 Nov 2017, 3(11), e1600983. https://doi.org/10.1126/sciadv.1600983

Hoffman, P. F., Kaufman, A. J., Halverson, G. P., \& Schrag, D. P. (1998). A Neoproterozoic snowball Earth. Science, 281(5381), 1342-1346. https://doi.org/10.1126/science.281.5381.1342

Huang, W. T., Dupont-Nivet, G., Lippert, P. C., van Hinsbergen, D. J. J., Dekkers, M. J., Waldrip, R., et al. (2015). What was the Paleogene latitude of the Lhasa terrane? A reassessment of the geochronology and paleomagnetism of Linzizong volcanic rocks (Linzhou Basin, Tibet). Tectonics, 34, 594-622. https://doi.org/10.1002/2014TC003787

Kirschvink, J. L. (1992). Late Proterozoic low-latitude global glaciation: The snowball Earth. In J. W. Schopf, \& C. C. Klein (Eds.), The Proterozoic Biosphere: A Multidisciplinary Study, (pp. 51-52). Cambridge: Cambridge University Press.

Köppen, W., \& Wegener, A. (1924). Die Klimate der Geologischen Vorzeit, (255 p). Berlin: Gebrüder Borntraeger. 
Köppen, W., \& Wegener, A. (2015). In J. Thiede, K. Lochte, \& A. Dummermuth (Eds.), transl. by B. OelkersThe climates of the geological past/Die Klimate der geologischen Vorzeit (reproduction and translation). Stuttgart: Borntraeger Science Publishers. $657 \mathrm{p}$

Kutzbach, J. E., Prell, W. L., \& Ruddiman, W. F. (1993). Sensitivity of Eurasian climate to surface uplift of the Tibetan plateau. The Journal of Geology, 101(2), 177-191. https://doi.org/10.1086/648215

Ladant, J. B., Donnadieu, Y., Lefebvre, V., \& Dumas, C. (2014). The respective role of atmospheric carbon dioxide and orbital parameters on ice sheet evolution at the Eocene-Oligocene transition. Paleoceanography, 29, 810-823. https://doi.org/10.1002/2013PA002593

Lippert, P. C., van Hinsbergen, D. J. J., \& Dupont-Nivet, G. (2014). Early Cretaceous to present latitude of the central proto-Tibetan Plateau: A paleomagnetic synthesis with implications for Cenozoic tectonics, paleogeography, and climate of Asia. In J. S. Nie, G. D. Hoke, \& B. K. Horton (Eds.), Toward an improved understanding of uplift mechanisms and the elevation history of the Tibetan Plateau, (pp. 1-21). Boulder, Co.: Geological Society of America. https://doi.org/10.1130/2014.2507(01)

Livermore, R., Nankivell, A., Eagles, G., \& Morris, P. (2005). Paleogene opening of Drake passage. Earth and Planetary Science Letters, 236(1-2), 459-470. https://doi.org/10.1016/j.epsl.2005.03.027

Macdonald, F. A., Schmitz, M. D., Crowley, J. L., Roots, C. F., Jones, D. S., Maloof, A. C., et al. (2010). Calibrating the Cryogenian. Science, 327(5970), 1241-1243. https://doi.org/10.1126/science.1183325

Milanković, M. (1998). Canon of Insolation and the Ice-Age Problem, (634 p). Beograd: Zavod zaudžbenike i nastavna sredstva.

Najman, Y., Appel, E., Boudagher-Fadel, M., Bown, P., Carter, A., Garzanti, E., et al. (2010). Timing of India-Asia collision: Geological, biostratigraphic, and palaeomagnetic constraints. Journal of Geophysical Research Solid Earth, 115(B12), B14416. https://doi.org/ 10.1029/2010JB007673

Partridge, T. C. (1997). Late Neogene uplift in eastern and southern Africa and its paleoclimatic implications. In W. F. Ruddiman (Ed.), Tectonic uplift and climate change, (pp. 63-70). New York: Plenum. https://doi.org/10.1007/978-1-4615-5935-1

Ramstein, G., Fluteau, F., Besse, J., \& Joussaume, S. (1997). Effect of orogeny, plate motion and land-sea distribution on Eurasian climate change over the past 30 million years. Nature, 386(6627), 788-795. https://doi.org/10.1038/386788a0

Raymo, M. E., \& Ruddiman, W. F. (1992). Tectonic forcing of Late Cenozoic climate. Nature. vol. 359, (6391); Research Library Core pg. 117, 6391, 122, DOI: https://doi.org/10.1038/359117a0

Rind, D. G., Russell, G., \& Ruddiman, W. F. (1997). The effects of uplift on ocean-atmosphere circulation. In W. F. Ruddiman (Ed.), Tectonic uplift and climate change, (pp. 123-147). New York: Plenum. https://doi.org/10.1007/978-1-4615-5935-1

Rögl, F. (1999). Mediterranean and Paratethys. Facts and hypotheses of an Oligocene to Miocene paleogeography (short overview) Geologica Carpathica, 50, 339-349.

Ruddiman, W. F. (1997). Tectonic Uplift and Climate Change. New York: Plenum. https://doi.org/10.1007/978-1-4615-5935-1

Ruddiman, W. F., \& Kutzbach, J. E. (1989). Forcing of late Cenozoic northern hemisphere climate by plateau uplift in southern Asia and the American west. Journal of Geophysical Research Atmospheres, 94(D15), 18409-18427. https://doi.org/10.1029/JD094iD15p18409

Scotese, C. R. (2001). Digital paleogeographicmap archive on CD-ROM (PALEOMAP Project).

Sepulchre, P., Arsouze, T., Donnadieu, Y., Dutay, J.-C., Jaramillo, C., Le Bras, J., et al. (2014). Consequences of shoaling of the central American seaway determined from modeling Nd isotopes. Paleoceanography, 29, 176-189. https://doi.org/10.1002/2013PA002501

Sepulchre, P., Ramstein, G., Fluteau, F., Schuster, M., Tiercelin, J. J., \& Brunet, M. (2006). Tectonic uplift and Eastern Africa aridification Science, 313, 1419-1423. https://doi.org/10.1126/science.1129158

Su, B., Jiang, D., Zhang, R., Sepulchre, P., \& Ramstein, G. (2018). Difference between the North Atlantic and Pacific meridional overturning circulation in response to the uplift of the Tibetan plateau. Climate of the Past Discussions, 14(6), 751-762. https://doi.org/10.5194/cp-14751-2018

Tan, N., Ladant, J. B., Ramstein, G., Dumas, C., Bachem, P., \& Jansen, E. (2018). Modeling Greenland ice sheet evolution during the PlioPleistocene transition: New constraints for $\mathrm{pCO}_{2}$ pathway. Nature Communications, 9(1), 4755. https://doi.org/10.1038/s41467-01807206-w

Tan, N., Ramstein, G., Dumas, C., Contoux, C., Ladant, J. B., Sepulchre, P., et al. (2017). Exploring the MIS M2 glaciation occurring during a warm and high atmospheric $\mathrm{CO}_{2}$ Pliocene background climate. Earth and Planetary Science Letters, 472, 266-276. https://doi.org/ 10.1016/j.epsl.2017.04.050

Van der Voo, R., Spakman, W., \& Bijwaard, H. (1999). Tethyan subducted slabs under India. Earth and Planetary Science Letters, 171(1), 7-20. https://doi.org/10.1016/S0012-821X(99)00131-4

Vavrus, S., \& Kutzbach, J. E. (2002). Sensitivity of the thermohaline circulation to increased $\mathrm{CO}_{2}$ and lowered topography. Geophysical Research Letters, 29(11), 1546. https://doi.org/10.1029/2002GL014814

Walker, J. C. G., Hays, P. B., \& Kasting, J. F. (1981). A negative feedback mechanism for the long-term stabilization of Earth's surface temperature. Journal of Geophysical Research, 86(C10), 9776-9782. https://doi.org/10.1029/JC086iC10p09776

Zhang, R., Jiang, D., Ramstein, G., Zhang, Z., Lippert, P. C., \& Yu, E. (2018). Changes in Tibetan plateau latitude as an important factor for understanding east Asian climate since the Eocene: A modeling study. Earth and Planetary Science Letters, 484, 295-308. https://doi.org/ 10.1016/j.epsl.2017.12.034

Zhang, R., Jiang, D., Zhang, Z., Cheng, Z., \& Zhang, Q. (2017). Comparison of surface uplifting climate effects of the northern Tibetan Plateau, the Tianshan, and the Mongolian Plateau on East Asian climate. Journal of Geophysical Research: Atmospheres, 122, 7949-7970. https://doi.org/10.1002/2017JD026470

Zhang, Z., Nisancioglu, K. H., Flatøy, F., Bentsen, M., Bethke, I., \& Wang, H. (2011). Tropical seaways played a more important role than high latitude seaways in Cenozoic cooling. Climate of the Past, 7(3), 801-813. https://doi.org/10.5194/cp-7-801-2011

Zhang, Z., Ramstein, G., Schuster, M., Li, C., Contoux, C., \& Yan, Q. (2014). Aridification of Sahara caused by Tethys Sea shrinkage during Late Miocene. Nature, 513(7518), 401-404. https://doi.org/10.1038/nature13705

Zhang, Z., Wang, H., Guo, Z., \& Jiang, D. (2007). What triggers the transition of paleoenvironmental patterns in China, the Tibetan Plateau uplift or Paratethys Sea retreat? Palaeogeography Palaeoclimatology Palaeoecology, 245, 317-331. 